\title{
Research on the Necessity, Challenge and Focus of Internationalization of Higher Education
}

\author{
Lin Jiang1,2 \\ ${ }^{1}$ Yancheng Teachers University, Yancheng, China \\ ${ }^{2}$ Nanjing University of Aeronautics and Astronautics, Nanjing, China \\ Email: jiangl@yctu.edu.cn
}

How to cite this paper: Jiang, L. (2022). Research on the Necessity, Challenge and Focus of Internationalization of Higher Education. Open Journal of Social Sciences, 10, 180-190.

https://doi.org/10.4236/jss.2022.102012

Received: January 27, 2022

Accepted: February 15, 2022

Published: February 18, 2022

Copyright $\odot 2022$ by author(s) and Scientific Research Publishing Inc. This work is licensed under the Creative Commons Attribution International License (CC BY 4.0).

http://creativecommons.org/licenses/by/4.0/ (c) (i) Open Access

\begin{abstract}
This paper analyzes the necessity (political motivation, revenue motivation, talent motivation, cultural motivation) and challenges (input-side challenges and output-side challenges) of internationalization of higher education based on the background of the rapid development of the discipline of "global studies", the fierce competition in higher education, and the domestic "double first-class" strategy. It proposes six points of focus for future internationalization of higher education based on research-review-archive-collaborationpolicy-help, with a view to providing a better solution for the country, universities, teachers and students. It is intended to provide some ideas for the internationalization development of the country, universities, teachers, students and other educational subjects.
\end{abstract}

\section{Keywords}

Higher Education, Internationalization, Necessity, Challenge, Focus

\section{Necessity of Internationalization of Higher Education}

Along with economic globalization and the evolution of the global governance system, "global studies" has become a comprehensive and emerging discipline and is growing rapidly. I searched for "Global Studies" on the Web of Science website and found 816,871 publications in various fields, the largest being Environmental Sciences Ecology, with 179,691 publications. The largest number of publications was in Environmental Sciences Ecology, with 179,691 publications; the smallest was in Cell Biology, with 52,475 publications, as shown in Figure 1. This number is very large, and we have reason to believe that "global science" has become a hot spot for research. Higher education is the highland of science and technology and intellectual wisdom, and is characterized by openness, 


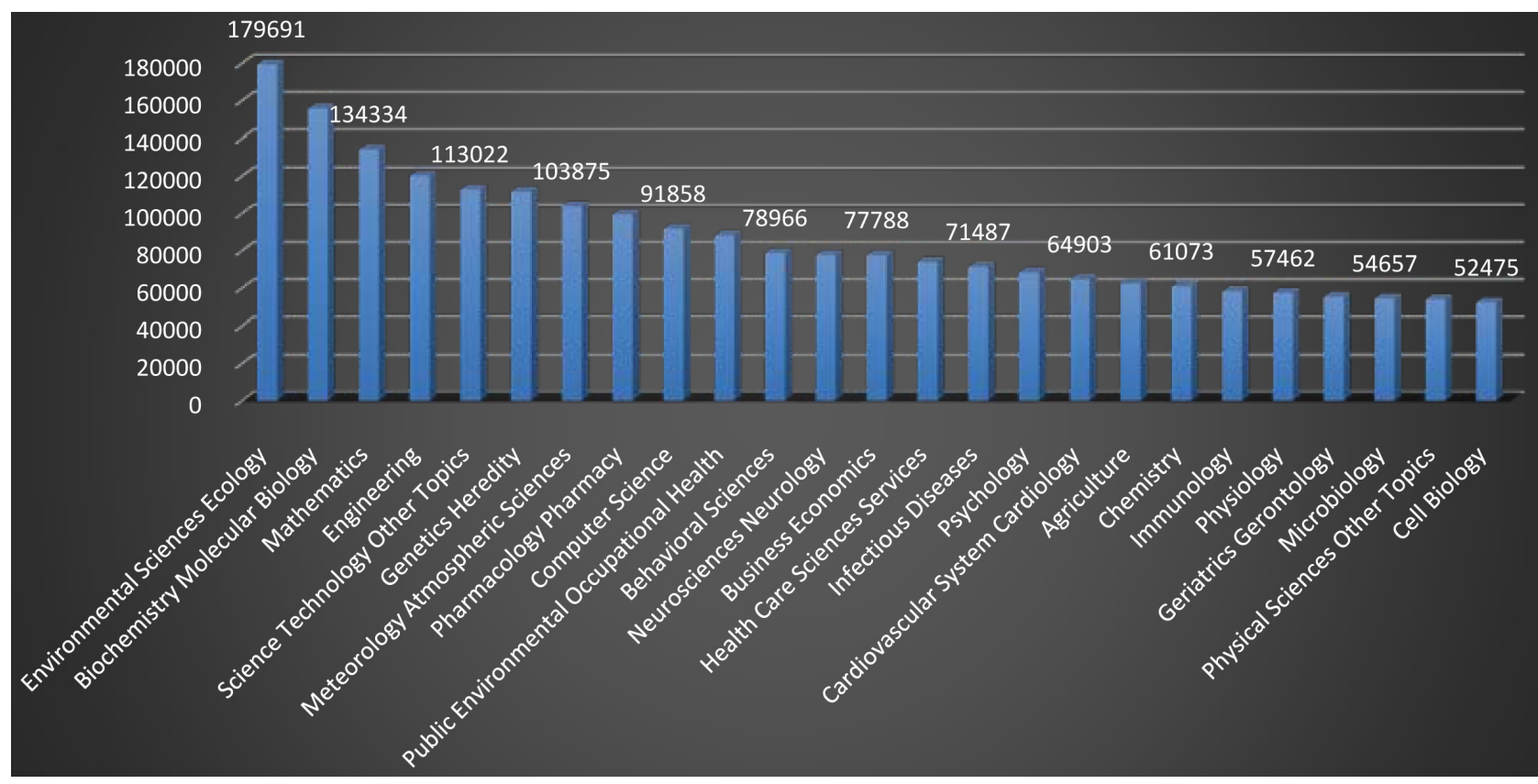

Figure 1. Number of publications in the Web of Science for each field of study "Global Studies".

tolerance, and innovation, as well as fierce competition. The internationalization of higher education has undergone revolutionary changes, embedding the attributes of internationalization into the functions of teaching, research and social services of universities.

The internationalization of higher education has political motives, and the internationalization of higher education and the internationalization strategy of national macro policies are based on each other, interdependent and mutually supportive, and show the basic, global and pioneering nature in China's "Belt and Road" strategy (Hu \& Shi, 2018). The internationalization of higher education is an important foundation for serving the political, economic, cultural and social development of the country. The new epidemic has brought a serious impact on the internationalization of higher education worldwide, which has intensified the changes of internationalization of higher education. In the post-epidemic era, the internationalization of higher education should not only be shifted from economic drive to cultural understanding, and a new model of diversified and sustainable internationalization of higher education should be built, but also the diversity of internationalization of higher education should be improved. Internationalization is a long-term strategy for the development of higher education, and macro policies are one of the supporting conditions.

The internationalization of higher education has gain motives, including economic gain, teaching gain and academic gain. Internationalization of higher education can build a dialogue system, achieve international interoperability, enhance academic influence, and expand international discourse. Internationalization of higher education can expand the international influence of national higher education and expand the source of income. Teachers visiting abroad gain both internal (teaching and research innovation ability) and external (edu- 
cational philosophy) significant benefits (Wang \& Wang, 2018). Attracting outstanding students from abroad can alleviate the student source crisis of universities.

Internationalization of higher education has talent motivation, which is conducive to improving the quantity and quality of internationalization of talents. A study of Changjiang scholars found that: internationalized education background, direct training method of undergraduate and doctoral studies, cross-cutting disciplines can accelerate the formation of top talents, and the degree of international participation of teachers and their professional teaching, scientific research and social service development level show an obvious positive correlation (Li \& Tang, 2022). The internationalization of higher education is the requirement of China's social development and the important guarantee of talent cultivation. As China's higher education enters the stage of double first-class, it should strive to realize the shift to "providing a kind of experience for other countries and the world to learn from". The number of international journal papers published by returnee teachers, the international content or international perspective of courses, the number of international academic conferences attended, and the number of overseas training experiences are more.

The internationalization of higher education has cultural motives, which is conducive to the spread of local culture and the integration of multiple cultures. The essence of internationalization of higher education is a kind of cultural momentum building, energy accumulation and influence, which is the interaction and symbiosis of multiple cultures ( $\mathrm{Li} \& \mathrm{Niu}, 2015)$. Traditional local culture is closely related to the internationalization development of local colleges and universities, which can influence and show the individual characteristics of internationalization development of local colleges and universities (Wang, 2014). The content construction, technology application and cultural communication of foreign language websites of colleges and universities are lagging behind the current internationalization development needs (Gu \& Yi, 2019). Chinese language is the basis of Chinese culture and the core of national soft power, so it is necessary to set off a wave of Chinese language fever in the world.

\section{Internationalization of Higher Education Is Challenging}

Internationalization is an inevitable choice for the development of higher education, but in practice, there are various potential conflicts, risks and challenges on the input side (international students and high-level overseas talents) and the output side (teachers and students). The main challenges on the input side are the lack of attraction of high-quality talents, the need to improve the quality of education and international reputation, the insufficient guarantee of the platform for imported high-level overseas talents, and the dual-track system of international students' management which is not conducive to academic integration. The main challenges on the export side are weak foundation of internationalization awareness, participation level and foreign language proficiency, high 
cost expenditure and limited channels, potential ideological risks, and brain drain risks.

\subsection{Importers' Challenge: To Absorb Teachers and Students to Work, Study and Learn in Our Country}

\subsubsection{Insufficient Attraction of High Quality Talents}

In order to promote domestic knowledge innovation and supplement the quality workforce, developed countries tend to attract high-level international students for study abroad education, and there is a big gap between China and developed countries in the proportion of high-level international students. The majority of international students coming to China originate from developing countries and geographically neighboring countries such as Japan and Korea, while Chinese universities are significantly less attractive to international students from developed countries.

\subsubsection{Teaching Quality and International Reputation Need to Be Improved}

Students are more concerned about factors such as teaching quality accreditation, academic reputation, market recognition, and immigration policies. From the QS World University Rankings, the world's major destination countries gather the best higher education institutions and are the main destination countries and institutions for international student mobility (Aaron, 2021).

\subsubsection{The Platform Guarantee of the Introduced Overseas High-End Talents Is Not Enough}

The differences in country, policy environment and process habits make it impossible for overseas high-level talents to adapt to the environment quickly and give full play to their advantages, especially when they feel that the procedures are too cumbersome and they lack local academic experience, resulting in a waste of talents. Some "hard conditions" cannot meet the personalized and specialized needs of overseas high-level talents, while the "soft environment" lacks good communication and guidance, and the platform is not enough to ensure the positive interaction with local talents in evaluation, management and integration, which eventually brings The problem of "bringing in but not keeping" (Bian, Jiang, \& Yang, 2021).

\subsubsection{The Two-Tier System of International Student Management Is Not Conducive to Academic Integration}

Due to the different cultural backgrounds, study backgrounds and living backgrounds of international students, international students are prone to cross-cultural, cross-regional and cross-language adaptation problems. In the management of international students, the education of international students and local students is implemented in a dual-track system, which is relatively independent of each other and the standard of international students' cultivation is not strict, which largely hinders the communication and integration between them. 


\subsection{Exporters' Challenge: Sending Teachers and Students to Study and Learn Abroad}

\subsubsection{Weak Foundation of Internationalization Awareness, Participation Level, and Foreign Language Proficiency}

A survey of some international students found that $14.3 \%$ of students and $17.4 \%$ of teachers had a "totally disapproving" or "dispensable" attitude toward internationalization, $90.0 \%$ of teachers thought that internationalization was "too demanding and difficult to achieve", $85.1 \%$ of teachers had no experience abroad for one year or more, $86.3 \%$ of students rated themselves as "poor" or "very poor" in foreign languages, and $58.1 \%$ of teachers were unable to meet the requirements. It is too demanding and difficult to achieve", $85.1 \%$ of teachers do not have one year or more of foreign experience, $86.3 \%$ of students' self-evaluation of foreign language is "poor" or "very poor", and $58.1 \%$ of teachers are not proficient in using $58.1 \%$ of teachers are not proficient in using foreign languages for classroom teaching (Xu \& Feng, 2021).

\subsubsection{High Cost and Limited Channels}

If education is viewed as an investment, there are educational costs and educational benefits, as well as educational investment risks. The costs of internationalization include psychological costs such as distance, time difference, language, history, and environment, and also include economic costs such as tuition, accommodation, and travel expenses, which are much higher than domestic education. In addition, family, friends, community social networks, and university international cooperation agreement networks can affect mobility trends, and there is currently a lot of room for expansion through personal and official channels.

\subsubsection{Potential Ideological Risks}

The inward-looking character of the national ideological discourse has greatly restricted the foreign dissemination of Chinese values, resulting in some international publics having little knowledge of China's modernization process (Liang \& Qi, 2021). In the context of international talent cultivation, the special nature of educational subjects, the functionality of educational models and the reality of talent competition are always challenging the ideological educators of university students, who are always seeking for faster and better methods and paths.

\subsubsection{Brain Drain Risk}

A large number of top talents inevitably enter the international labor market during their education and consumption activities abroad, resulting in the loss of domestic talents and economic losses; some of the top talents entering the international market are precisely scarce talents, causing a fault line in the domestic labor market and some industries. 2013The number of China's top talents was the highest in the world in 2011, among which an average of $87 \%$ of talents in science and engineering fields stayed abroad, and most of those who have not returned to the U.S. are doctoral talents in science and technology 2008. 


\section{The Focus of Internationalization of Higher Education}

I searched for "Internationalization of Higher Education" in Web of Science, and entered the abstracts of the most relevant 100 papers into Gooseeker software for word separation, word selection and co-linear matching, and then entered the co-linear matching matrix generated by the system into Gephi software for cluster analysis.

According to Figure 2, we can see that the promotion of internationalization of higher education requires six areas of effort, including advocacy-reviewarchive-cooperation-policy-assistance.

\subsection{National and Institutional Research and Advocacy on Internationalization of Higher Education}

The competition of higher education is essentially the competition of higher education quality, and the large scale of higher education does not mean a strong education country. To build a strong education country, we must take the road of internal development, satisfy students and people, and grasp the lifeline of education quality. According to the survey, the factors of "excellent teaching quality assessment" account for $22 \%$ and "student satisfaction rate" account for $36 \%$ when international students choose a school; the factors of "high quality teaching" account for $32 \%$ and "student satisfaction rate" when choosing a major. The factors of "high quality teaching" accounted for 32\%, "reasonable tuition fee" accounted for 25\%, and "university ranking" accounted for $19 \%$ when choosing a major (Feng, 2021). Therefore, in order to attract international mobility of high quality human resources, both countries and institutions need to study the methods, policies, prices, supply chains, influencing factors, talent management, disciplines, resources, curricula, etc. of internationalization of

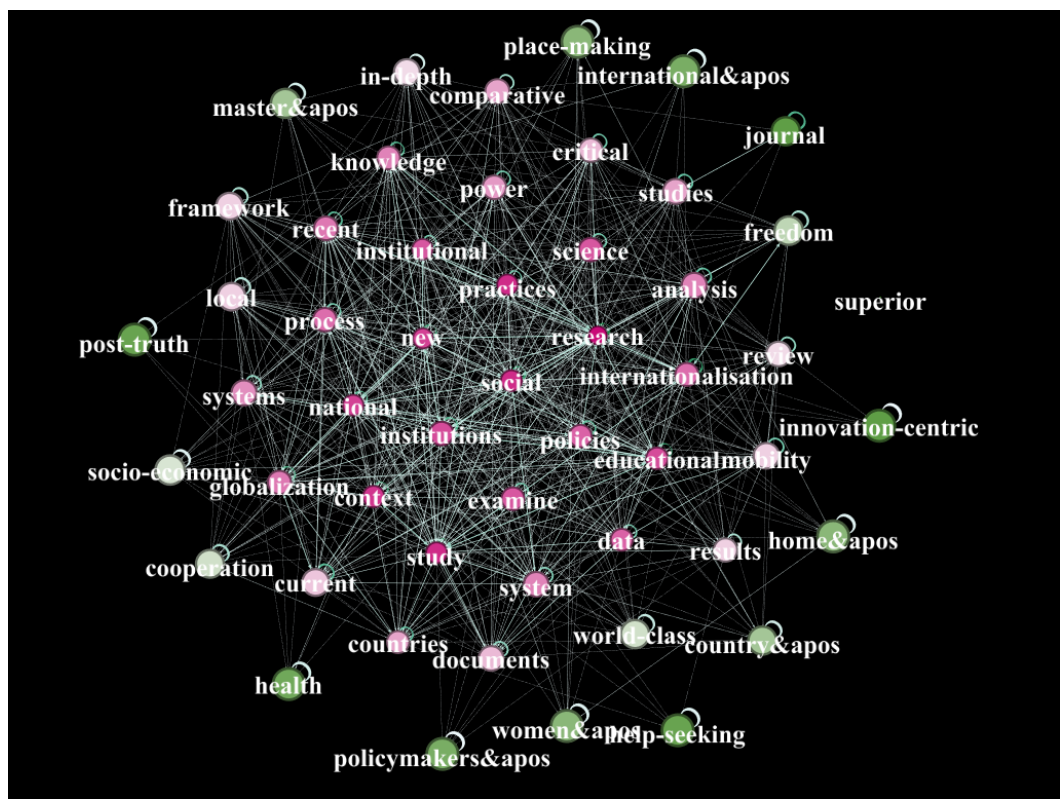

Figure 2. Keyword clustering map of internationalization methods in higher education. 
higher education, as well as to expand the publicity of the ranking of internationalized institutions, quality of teaching and research, and student satisfaction rates.

\subsection{Formation of Systematic Data Based on National Political Screening - Social Background Screening}

There are political risks in internationalization of higher education, so both teachers and students involved in internationalization of higher education should combine internationalization with ideological and political education, with the community of human destiny, with family feeling, with cultural confidence, and with world view, life view, values, and methodology. It is necessary to conduct political and social background review, and form systematic data that can be tracked. Educator Shi Yigong said, "Patriotism is the most simple feeling, who does not love his mother?" The public and morality are the sentiments of teachers and students, and "the rise and fall of the country is the responsibility of everyone". We need to stimulate teachers and students' innovation and creativity, ignite their passion for struggle, and guide them to serve the overall development of the country. It firmly establishes the family sentiment of internationalized talents and the Chinese national spirit with patriotism as the core, thus inspiring the innovation and development of high-level talents.

\subsection{Formation of an Archive of Knowledge, Processes and Results of Internationalization of Higher Education}

At present, the internationalization of higher education increasingly shows the development tendency of extending to the knowledge system, and the setting of internationalized knowledge system must be based on the concept of internationalization, highlighting the integrity, respecting the development law of internationalized curriculum, emphasizing the development of teachers and students individually, focusing on the internationalization of learning concept, internationalization of learning content, internationalization of learning method, internationalization of knowledge cooperation, internationalization of process management and The internationalization of learning concepts, internationalization of learning contents, internationalization of learning methods, internationalization of knowledge cooperation, internationalization of process management, and internationalization of result files. It is necessary for universities or institutions to embed full English courses with first-class teachers who are fully committed to teaching, to offer full English courses to all domestic and international students, to continuously optimize teaching methods and assessment methods, to create a multicultural environment, and to promote mutual learning and joint growth of domestic and international students. Generally speaking, the development of knowledge scale of internationalization of higher education cannot meet the needs of the society, the introduction of the curriculum resources of world famous universities is also insufficient, and the quality of schooling needs to be further monitored and improved, so the knowledge, process and result files 
of internationalization of higher education should be formed, taking into account the coordination of four levels: scale development and structural adjustment, internationalization and nationalization, legal governance and independent schooling, quality assurance and cultivation of high quality The development of internationalization.

\subsection{Collaborate with Local World-Class Institutions and Journals to Study the Mobility of Talent}

High-level talents have a certain degree of stability, and mobility may occur only under the conditions of more promising development platforms, more lucrative salary and compensation, and a superior research living environment. Strengthen the cooperation with local world-class institutions and journals to study the mobility of talents. Cooperation can be policy cooperation or financial cooperation, but the willingness and quality of cooperation should be enhanced. The release of talent mobility stimulates individual innovation behavior and is an initiative to promote the transformation of innovation activities from public sector innovation to innovation for all. Government departments can increase human capital mobility, stimulate individual innovation and promote the transformation of innovation models by increasing the introduction of talent and establishing a talent guarantee mechanism. The mobility of different types of talents is different, and some studies show that the mobility of management talents is the largest and the mobility of technical skills talents is the smallest. Therefore, we should analyze the mobility of talents, measure the mobility index framework from qualitative and quantitative perspectives, study the dominant forces, current situation, trends and institutional barriers of talent mobility, and put forward countermeasure suggestions to further promote talent mobility.

\subsection{Develop Long-Term and Short-Term Internationalization Policies to Build an Internationalized Innovation Center}

Internationalization of higher education requires both long-term and short-term policies that work together, with both a sense of global radiation and regional and country-specific prioritization, while maintaining a balance between import and export in terms of orientation. Various countries and regions have adopted a series of measures to strengthen the communication skills, social interaction, cultural empathy, and environmental adaptability of human resources ( $\mathrm{Wu} \&$ Zhang, 2021). Singapore has taken initiatives such as internationalization of talents, internationalization of curriculum, cooperation with well-known international companies, and international training. Germany has taken measures to increase investment in research, reform the academic system, provide diversified scholarship programs, and develop a facilitated visa employment policy. The internationalization of higher education in the United States and the European Union is characterized by the integration of resources, relying on cooperation and having different focuses (Shi, 2020). Contemporary talents need to enhance global vision, cultivate global consciousness, enhance the concept of community, 
be more open-minded, more tolerant, more rational, and more universal in their approach and cooperation, and build a community of human destiny (Yu, 2018). We should build an internationalized innovation center, and the framework of inter-campus cooperation with cross-border research, faculty and student exchange, curriculum sharing, credit transfer, and degree awarding should become the core of internationalization activities (Wu \& Huang, 2021). We need to learn English as a compulsory subject and take the initiative to "go out" and invest directly in higher education overseas (Cui \& Wen, 2022). The administrators who are engaged in internationalization of higher education must broaden their international perspective, be good at international comparison, be good at service, provide a platform, and enhance the operability of policies. Increase the amount of funding for diversified foreign language study and regional studies, and increase efforts to attract overseas teachers and international students.

\subsection{Provide Assistance Outside of the Country and Improve the Financial and Health Status of Students}

In the framework of global consciousness, we provide help for internationalization service. In terms of platform, we make overseas investment, inter-university cooperation, teacher cooperation, student cooperation, etc.; in terms of fund, we strive for national investment, provincial investment, university investment, other project investment, etc.; in terms of ability, we improve English ability, communication ability, social interaction ability, environmental adaptation ability, etc.; in terms of management, we increase internationalization, build management service team In terms of management, we should increase internationalization, build management service team, pay attention to balanced input and output, and equip with agreed legal advisors; in terms of characteristic development, we should find the characteristics, merits and focus of universities and teachers themselves. Using the push-pull theory, we can both boost and pull the enthusiasm and participation of teachers and students in internationalization, and take the participation of all people as the goal, and consider improving the economic and health conditions of students, and attach to the national and provincial "Thousand Talents Plan", "Ten Thousand Talents Plan", "Specially Appointed Professor", "Specially Appointed Professor" and "Specially Appointed Professor". "Specially Appointed Professor", "Youth and Blue Project", "333 Project", "111 Project", and The "Talent Summit" and other talent policies, build a platform for door-to-door services, simplified procedures, agreements, communication and coordination, and supporting teams, and provide more generous "hardware" facilities, such as research start-up funds, equipment, performance incentives, and a comprehensive evaluation system based on morality. We can also provide some "software" care, such as life protection, health protection, children's education protection, etc.

\section{Conclusion}

This paper introduces the political, revenue, talent, and cultural drivers of higher 
education, showing that internationalization of higher education has the inevitability of "global" development. At the same time, internationalization of higher education faces challenges on the input side in terms of talent attractiveness, teaching quality and international reputation, platform security and academic integration, and challenges on the output side in terms of foundation, cost, ideology and brain drain risk. Finally, based on the cluster analysis method of literature research, we obtain six focus points of internationalization of higher education based on advocacy-review-archive-cooperation-policy-help, and expand to explain the specific promotion methods of focus points. The study also explains how to promote the points of emphasis. We can open up the future only if we do not forget the history, and we can innovate only if we inherit well. The internationalization of higher education is important, and many countries, universities and institutions are looking for effective ways to promote it, and the research in this paper hopes to give researchers some suggestions and thoughts. In conclusion, it is important to cultivate cultural confidence and patriotism among teachers and students, understand the necessity and challenges of internationalization of higher education, learn innovative practices and successful cases from various countries, universities and disciplines in every aspect, and come out with a differentiated development path to promote internationalization of higher education so that innovation can be promoted continuously. Of course, this paper only stops at the combing of literature and the statement of suggestions at present, and the research on the assessment of higher education internationalization based on quantitative data will be considered later.

\section{Acknowledgements}

1) Jiangsu Province Education Reform and Development Strategic and Policy Research Major Project: Jiangsu high-level teacher team construction research, Project No. 202000206.

2) Project of Jiangsu Provincial Education Department: Research on talent management innovation of universities based on big data in the context of “double first-class", Project No. 72031941028A.

\section{Conflicts of Interest}

The author declares no conflicts of interest regarding the publication of this paper.

\section{References}

Aaron, A. (2021). Changes in U.S. International Student Mobility Policies and Their Internal Logic-A Perspective Based on Intermittent-Equilibrium Theory. Higher Education Exploration, No. 10, 77-84.

Bian, L. R., Jiang, H. N., \& Yang, M. J. (2021). Analysis of Innovation Output Pattern of Overseas Returnees from Universities in Yangtze River Delta. World Regional Studies, No. 30, 1219-1229.

Cui, Y. N., \& Wen, W. (2022). Progress and Challenges of Sino-Thai Higher Education 
Cooperation and Exchange. Journal of Higher Education Management, No. 16, 100-109.

Feng, L. (2021). Reconciling Multiple Interests in the Evaluation of British Universities-An Example of the Excellence Framework System. Studies in Foreign Education, No. 48, 73-86.

Gu, Y. Q., \& Yi, Y. G. (2019). Construction of Multilingual Foreign Language Websites in Chinese Universities: Current Situation, Problems and Countermeasures. Applied Linguistics, No. 1, 46-55.

Hu, D. X., \& Shi, Z. (2018). The Deep Integration of “One Belt and One Road" Initiative and Internationalization of Chinese Higher Education. Higher Education Exploration, No. 7, 10-16.

Li, F., \& Tang, L. (2022). Can Overseas Experience Accelerate Career Development: The Case of Changiiang Scholars. Science Research Management, No. 43, 192-199.

Li, L. Y., \& Niu, J. M. (2015). The Essence and Connotation of Internationalization of Higher Education: The Perspective of Cultural Flow. Higher Education Exploration, No. 11, 36-41.

Liang, C., \& Qi, Z. Y. (2021). Regulatory Risks and Effective Prevention and Control of Overseas Higher Education Institutions Running Independent Schools. Higher Education Exploration, No. 9, 19-26.

Shi, Y. (2020). Inter Nationalization of Higher Education in the United States and National Strategy. Educational Research, No. 41, 66-80.

Wang, L., \& Wang, S. Y. (2018). A Study on the Development Status and Schooling Practice of Overseas Branches of British Universities-Taking Heriot-Watt University Dubai as an Example. Studies in Foreign Education, No. 9, 3-22.

Wang, Y. (2014). Analysis of the Influence of Culture on the Internationalization Development of Local Universities and Countermeasures. Contemporary Education and Culture, No. 7, 104-108.

Wu, A., \& Zhang, Z. H. (2021). Policies and Practices of International Development of Higher Education in Russia. China Higher Education, No. 2, 75-77.

Wu, H., \& Huang, F. T. (2021). An Empirical Study on the Internationalization Activities of Japanese University Teachers and Their Influencing Factors-An Analysis of the Results Based on the APIKS National Questionnaire Survey. Tsinghua Journal of Education, No. 42, 55-63.

Xu, X. Z., \& Feng, J. C. (2021). The Path of Cultivating Internationalized Talents in Philosophy and Social Sciences in the New Era-An Analysis Based on Rooting Theory. China Higher Education Research, No. 6, 37-43.

$\mathrm{Yu}$, W. L. (2018). Cultivation of Global Consciousness of Contemporary Chinese in the Context of the Community of Human Destiny. Academic Forum, No. 2, 45-50. 